\title{
The Effect of Grassland Management History on Soil Carbon Response to Slurry and Urea
}

\author{
Junfang Cui ${ }^{*}$, Nicholas M. Holden² \\ ${ }^{1}$ Institute of Mountain Hazards and Environment, CAS, Chengdu, China \\ ${ }^{2}$ UCD School of Biosystems Engineering, University College Dublin, Dublin 4, Ireland \\ Email: ^jfcui@imde.ac.cn, nick.holden@ucd.ie
}

How to cite this paper: Cui, J.F. and Holden, N.M. (2017) The Effect of Grassland Management History on Soil Carbon Response to Slurry and Urea. Open Access Library Journal, 4: e4072. https://doi.org/10.4236/oalib.1104072

Received: October 25, 2017

Accepted: November 14, 2017

Published: November 17, 2017

Copyright $\odot 2017$ by authors and Open Access Library Inc.

This work is licensed under the Creative Commons Attribution International License (CC BY 4.0).

http://creativecommons.org/licenses/by/4.0/

cc) (7) Open Access

\begin{abstract}
Slurry and urea applications are part of normal nutrient management on grassland farms utilizing grazed grass and silage for animal production. It was hypothesized that management history would result in a different carbon response to slurry and urea applications for the same soil type because of differences in soil micro-environment, including microbial biomass and activity, are formed and regulated by long-term management history. An Irish grassland soil of the Skeagh Series was sampled in three fields, each with a long, consistent management history: Soil A was associated with extensive grazing by horses; soil B with medium intensity grazing by sheep and cattle, and grass silage conservation; and soil $\mathrm{C}$ with intensive dairy cow grazing. There were three slurry treatments $\left(S_{1}\right.$, the control of no slurry; $S_{2}$, slurry mixed with soil; $\mathrm{S}_{3}$, slurry added on the soil surface) and three urea treatments $\left(\mathrm{N}_{1}\right.$, the control of no urea; $\mathrm{N}_{2}$, all urea applied at one time; and $\mathrm{N}_{3}$, three application, 30 days apart, totaling the same amount of urea as $\mathrm{N}_{2}$ ) designed to supply $36 \mathrm{~g} \mathrm{C} \mathrm{m}^{-2}$ and $2 \mathrm{~g} \mathrm{~N} \mathrm{~m}^{-2}$ during an 85 day incubation trial. Soil $\mathrm{pH}$, total carbon, cold water extractable organic carbon, soil respiration and two C-related enzymes ( $\beta$-glucosidase and CM-cellulase) were measured. All measured soil properties showed a significant difference $(P<0.05)$ by management history, indicating a strong influence of long-term management on response. $\beta$-glucosidase and CM-cellulase activity showed a strong relationship with soil management history rather than with slurry or urea additions. It was concluded that management history was important to $\mathrm{C}$ dynamics. Slurry mixed with soil resulted in a greater soil carbon loss than slurry applied on the soil surface. One large dose of urea caused greater soil carbon loss than multiple small doses.
\end{abstract}

\section{Subject Areas}

Edaphology 


\section{Keywords}

Soil Carbon, Management History, Slurry, Urea, Enzyme

\section{Introduction}

Grass-based livestock production is the predominant agricultural system in Ireland and other countries where a humid climate suites grass production. Large volumes of animal excreta (slurry and manure) produced by animals mainly during winter housing must be recycled to the land. In Ireland, $87 \%$ of farms produced and spread slurry and manure in 2009, and slurry constituted over half of the total combined application of slurry and manure, of which 97\% of total slurry was applied to grassland with the remaining 3\% applied to maize or tillage crops. Urea application to pasture has declined in recent years due to its high price and environmental regulations (e.g. European Communities (Water Policy) Regulations 2003 (S.I.No. 722 of 2003) and Nitrate Directive (91/676/ EEC)), but urea is still required, especially in spring, to boost grass growth and overcome feed deficits [1].

There is some research on key processes regulating soil quality and the productivity impacts of slurry and urea applications [2] [3]. Soil under pasture subject to regular slurry application tends to have greater aggregate stability [4], which contributes to soil carbon sequestration and potentially results in significant offsets to greenhouse gas emissions [5]. Slurry also contributes to greater below-ground soil biodiversity [6], soil fertility, and soil carbon cycle processes [7]. Urea fertilizer is useful to increase net primary production and improve litter quality, despite evidence of decline in below-ground soil faunal diversity [8] [9], a relative high nutrient cycling rate and greater nutrient leaching [8]. Addition of $\mathrm{N}$ fertilizer influences soil carbon dynamics by changing the soil carbon to nitrogen ratio [10], which regulates soil microbial processes by governing soil microbial community composition [2] and enzyme activity [11].

Mismanagement of slurry and urea can lead to environmental problems and low nutrient efficiency (especially $\mathrm{N}$ use efficiency). Traditionally slurry is spread on pasture via "splashplate" application to distribute a thin film on the sward surface, resulting in odor and ammonia release [6]. Shallow injection of slurry into the soil can improve $\mathrm{N}$ efficiency [12] by reducing ammonia loss by $57 \%$ [13]. Overuse or improper application of urea can result in nitrate leaching and ammonia volatilization, leading to low $\mathrm{N}$ use efficiency [14] [15].

Knowledge of soil carbon dynamic response to slurry and urea application has tended to focus on understanding the short-term soil response [16] [17], but it is less clear how important long-term management is in the short-term control of soil respiration and soil enzyme activity. Since the soil micro-environment, which regulates the microbial community and its activity and thus other soil properties, is formed and regulated by long-term management as well as short 
term events, it is reasonable to think that soil carbon response to short-term slurry and urea addition to the soil will be regulated by antecedent conditions. In modern agriculture organic or inorganic fertilization and related management intensity are the main indicators of long-term management history. The objective of this study was to address the questions: i) does soil with differentlongterm management history (i.e. management intensity) respond differently to the same amount of mineral or organic fertilization? It was hypothesized that soil with a management history of lower intensity will have a delayed response to slurry and urea fertilizer application as the microbiological community adapts to the change in condition; ii) does slurry applied by mixing with the soil (imitating shallow injection) lead to greater $\mathrm{C}$ decomposition compared to slurry applied on soil surface (imitating traditional "splashplate" application)? It was hypothesized that slurry mixed with the soil will maintain greater microbial activity for longer thus leading to greater soil $\mathrm{C}$ decomposition. iii) does the same amount of nitrogen fertilizer added to the soil in one dose compared to multiple smaller doses result in less $\mathrm{C}$ decomposition? It was hypothesized that multiple smaller doses will maintain greater microbial activity over longer periods and will result in greater $\mathrm{C}$ decomposition. Using a single soil type, with three levels of longterm management history, an incubation experiment was conducted to test slurry application method and urea timing as part of normal grassland management.

\section{Material and Methods}

The soils were sampled from a farm under temperate, maritime climate in eastern Ireland with relatively mild, moist winters and cool, cloudy summers. The mean annual temperature was $9.4^{\circ} \mathrm{C}$ and the mean total annual precipitation was $869 \mathrm{~mm}$ from 1981-2010 at the nearby Dunsany weather station (www.met.ie). The grass sward was dominated by a mixture of perennial ryegrass and clover, typical of eastern Ireland. Three soils were collected from UCD Lyons Research Farm, located in Co. Kildare, Ireland (53 $\left.18^{\prime} 1 " \mathrm{~N} ; 6^{\circ} 33^{\prime} 2^{\prime \prime} \mathrm{W}\right)$ from fields with different management history. Soil A was from an extensively grazed field, having over 100 years grazing history, used for more than a decade to graze horses from March to November each year. Approx. $85 \mathrm{~kg} \mathrm{~N}$ per ha per year is applied but no slurry. Soil B was under medium grazing intensity for over 30 years and the sward was reseeded 4 years prior to sampling. It is used for sheep grazing from March to April and a mix of cattle and sheep from mid-August to November with a 4-week rotation depending on grass growth. In addition two cuts of silage are taken every year between May and August with a harvest of approx. $30 \mathrm{t} \mathrm{ha}^{-1}$ fresh grass (equivalents to approx. $9 \mathrm{t} \mathrm{ha}^{-1}$ dry matter). Soil $\mathrm{C}$ was under intensive grazing by dairy cows with a rotation of 4 to 5 weeks from February to November. The average yield per cow is around $70001 \mathrm{yr}^{-1}$ milk. Consistent management for over 30 years has been associated with about $33 \mathrm{~m}^{3}$ per ha cattle slurry and $140 \mathrm{~kg} \mathrm{~N}$ applied per ha in the last decade. All three soils were classi- 
fied as Skeagh Series, part of a gley association [18] with a USDA soil texture class of clay loam in the top $15 \mathrm{~cm}$ and a clay content of $31 \%$ to $33 \%$. There were $7.6 \mathrm{~m}^{3} \mathrm{ha}^{-1}$ cattle slurry and $175 \mathrm{~kg} \mathrm{~N} \mathrm{ha}^{-1}$ applied to soil B and soil C three weeks before the soils were sampled as part of routine farm management.

All soils were collected to a depth of $15 \mathrm{~cm}$ after removing the grass and thatch to expose the soil surface while avoiding contamination by surface plant residue. Stones and roots were removed in the field. Soil samples were stored at $4^{\circ} \mathrm{C}$ and sieved $(<5.6 \mathrm{~mm})$ within $12 \mathrm{~h}$ of collection.

\subsection{Incubation Experiment}

The experimental set-up comprised three soils and six independent treatments, consisting of three cattle slurry treatments (control treatment $S_{1}$, no slurry; $S_{2}$, slurry mixed with soil to inimate shallow injection; and $S_{3}$, slurry spread on soil surface to inimate "splashplate") and three urea treatments $\left(\mathrm{N}_{1}\right.$, the control of no urea; $\mathrm{N}_{2}$, all urea applied one time at the very beginning of incubation; $\mathrm{N}_{3}$, three application, 30 days apart totaling the same amount of urea as $\mathrm{N}_{2}$ ). The cattle slurry was collected from UCD Lyons Research Farm at the time of soil sampling. Physical and chemical characteristics are listed in Table 1 indicating a lower dry matter (DM) and total nitrogen (TN) content compared to typical values in Ireland [19] [20] [21]. Slurry equating to $36 \mathrm{~g} \mathrm{C} \mathrm{m}^{-2}$ was applied for slurry treatments (the $7.6 \mathrm{~m}^{3} \mathrm{ha}^{-1}$ applied to Soil B and C during routine farm management was equivalent to $27.3 \mathrm{~g} \mathrm{C} \mathrm{m}^{-2}$ ). Soil and slurry for treatment $\mathrm{S}_{2}$ were mixed and then transfered into germination pots (pot size: $8 \mathrm{~cm} \times 8 \mathrm{~cm} \times 6$ $\mathrm{cm}, 384 \mathrm{~cm}^{3}$; soil bulk density: $0.87 \mathrm{~g} \mathrm{~cm}^{-3}$ [22]; in total $317 \mathrm{~g}$ soil per pot). The same amount of soil for treatments $S_{1}$ and $S_{3}$ was transfered into the same size pots. There was no further addition for treatment $S_{1}$, but for treatment $S_{3} 5.76 \mathrm{~g}$ slurry was spread evenly on the surface of the soil in each pot. The same amount of soil was used in each cell for urea treatments. No futher additions were used for $\mathrm{N}_{1}, \mathrm{~N}_{2}$ received $10 \mathrm{ml} 5.76 \mathrm{~g} \mathrm{~L}^{-1}$ urea solution (equalent to $2 \mathrm{~g} \mathrm{~N} \mathrm{~m}^{-2}$ or $42 \mathrm{~kg}$ $\mathrm{ha}^{-1}$ ) and for treatment $\mathrm{N}_{3} 10 \mathrm{ml} 1.92 \mathrm{~g} \mathrm{~L}^{-1}$ urea solution was applied to the soil surface on three occations (day 0,31 and 61) during the incubation. $\mathrm{N}_{2}$ and $\mathrm{N}_{3}$ had applications equivalent to $13 \mathrm{~kg} \mathrm{~N} \mathrm{ha}^{-1}$. All pots were arranged randomly on trays and placed into an incubator at $23^{\circ} \mathrm{C} \pm 2^{\circ} \mathrm{C}$ and at $45 \%$ humidity. The incubation was for 85 days from June to August 2013. All pots received $10 \mathrm{ml}$ distilled water on the days of $\mathrm{N}_{3}$ treatments and during incubation, soil moisture

Table 1. Physical and chemical characteristics of the cattle slurry used in this experiment and characteristic values of cattle slurry from other farms in Ireland.

\begin{tabular}{cccc}
\hline $\mathrm{DM}\left(\mathrm{g} \mathrm{kg}^{-1}\right)$ & $\mathrm{TN}\left(\mathrm{kg} \mathrm{m}^{-3}\right)$ & $\mathrm{pH}$ & Reference \\
\hline $30.5 \pm 2.2$ & $2.0 \pm 0.1$ & $7.3 \pm 0.1$ & The present study \\
$62.7 \pm 20.7$ & $3.4 \pm 1.4$ & $7.3 \pm 0.2$ & Cui, Askari [19] \\
$105.0 \pm 4.0$ & $4.4 \pm 0.3$ & $7.5 \pm 0.1$ & Alaoui, Lipiec [20] \\
$59.1 \sim 80.5$ & $2.1 \sim 4.4$ & -- & Munkholm, Heck [21] \\
\hline
\end{tabular}


was regulated by weight losses by adding the appropriate amount of distilled water.

Soil samples were collected on day $1,4,7,14,21,28,32,56,58,62,71$ and 84 after incubation started. To avoid error caused by inter-sample contamination, two individual pots (as two replicates) were lifted from each treatment and used for soil analysis with the remaining soil discarded. Therefore, 144 pots of soil were incubated for each soil with 432 pots in total.

\subsection{Soil Analysis}

Each soil sample was analyzed for total carbon (TC) using $2 \mathrm{~mm}$ air-dried soil and dry combustion with a carbon analyzer (Primacs ${ }^{\text {SLC }}$, SKALAR Co.). Cold water extractable organic carbon (CWOC) was extracted by adding $20 \mathrm{ml}$ of distilled water to $5 \mathrm{~g}$ moist soil and shaking for 30 minutes in a rotating shaker before filtration and analysis with a liquid TOC analyzer (TOC- $\mathrm{V}_{\mathrm{CSH} / \mathrm{CSN}}$, SHIMADZU Co.). Soil $\mathrm{pH}$ was determined by preparing a soil to water $(\mathrm{w} / \mathrm{w})$ ratio of 1:2 (20 $\mathrm{ml}$ distilled water to $10 \mathrm{~g}$ 2-mm sieved soil).

Soil respiration (SR) was measured by incubating $20 \mathrm{~g}$ moist soil in a sealed jar along with a beaker containing $20 \mathrm{ml} 1 \mathrm{M} \mathrm{NaOH}$ in the dark at $25^{\circ} \mathrm{C}$ for 10 days [23]. The evolved $\mathrm{CO}_{2}$ was determined by titration with $0.5 \mathrm{M} \mathrm{HCl}$. Respiration was expressed as $\mu \mathrm{g}$ C- $\mathrm{CO}_{2} \mathrm{~g}^{-1} \mathrm{~h}^{-1}$. CM-cellulase (EC 3.2.1.4) activity was determined using the method of [24], where $5 \mathrm{~g}$ fresh soil was added to $15 \mathrm{ml} 2 \mathrm{M}$ acetate buffer ( $\mathrm{pH}$ 5.5) plus $15 \mathrm{ml} \mathrm{CM}$-cellulose substrate and incubated at $50^{\circ} \mathrm{C}$ for $24 \mathrm{~h}$. For photometric analysis, $1 \mathrm{ml}$ of thirty-fold diluted soil filtrate was added to $1 \mathrm{ml}$ anhydrous sodium carbonate solution plus $1 \mathrm{ml}$ of potassium ferric hexa-cyanide solution. The mixture was sealed and boiled in a water bath at $100^{\circ} \mathrm{C}$ for exactly $15 \mathrm{~min}$. The produced glucose was measured at $690 \mathrm{~nm}$ after adding color indicator and CM-cellulose activity was expressed as $\mu \mathrm{g}$ glucose $\mathrm{g}^{-1}$ soil $\mathrm{h}^{-1}$. $\beta$-glucosidase (EC 3.2.1.21) activity was tested by incubation of $1 \mathrm{~g}$ fresh soil added to $0.25 \mathrm{ml}$ toluene, $4 \mathrm{ml}$ of $\mathrm{MUB} \mathrm{pH} 6.0$ and $1 \mathrm{ml}$ PNG solution (p-nitrophenyl- $\beta$-D-glucoside, Sigma) at $37^{\circ} \mathrm{C}$ for $3 \mathrm{~h}$ [25]. The activity was expressed as $\mu \mathrm{g} \mathrm{p}$-nitrophenol $\mathrm{g}^{-1} \mathrm{~h}^{-1}$.

\subsection{Statistical Analysis}

Statistical analysis was performed using SPSS v. 20. One-way ANOVA was used to analyze for the effects of management history, slurry treatment, urea treatment and incubation time (days) on each soil property by soil and treatment. The interactions of incubation day, soil, slurry and urea treatments were assessed by MANOVA.

\section{Results}

Soil properties after sampling and before incubation (Table 2) were somewhat different. Soil A had the lowest $\mathrm{pH}, \mathrm{TC}$, respiration and CM-cellulase activity, Soil B had the the lowest $\beta$-glucosidase activity and soil C had the lowest CWOC. 
Table 2. Selected soil properties (means \pm S.E.) of soil A, B and C used in incubation trial.

\begin{tabular}{cccccccc}
\hline Soil & $\mathrm{pH}$ & $\begin{array}{c}\mathrm{TC} \\
\left(\mathrm{mg} \mathrm{g}^{-1}\right)\end{array}$ & $\begin{array}{c}\text { CWOC } \\
\left(\mu \mathrm{g} \mathrm{g}^{-1}\right)\end{array}$ & CWOC:TC & $\begin{array}{c}\text { Respiration } \\
\left(\mu \mathrm{CO}_{2}-\mathrm{C}\right. \\
\left.\mathrm{g}^{-1} \mathrm{~h}^{-1}\right)\end{array}$ & $\begin{array}{c}\beta \text {-glucosidase } \\
(\mu \mathrm{g} \text {-nitrophenol } \\
\left.\mathrm{g}^{-1} \mathrm{~h}^{-1}\right)\end{array}$ & $\begin{array}{c}\text { CM-cellulase } \\
(\mu \mathrm{g} \text { glucose } \\
\left.\mathrm{g}^{-1} \mathrm{~h}^{-1}\right)\end{array}$ \\
\hline A & $6.9 \pm 0.03 \mathrm{a}$ & $3.6 \pm 0.4 \mathrm{a}$ & $107 \pm 23 \mathrm{a}$ & $0.52 \pm 0.17 \mathrm{a}$ & $0.10 \pm 0.02 \mathrm{a}$ & $157 \pm 37 \mathrm{ab}$ & $18.5 \pm 7.3 \mathrm{a}$ \\
B & $7.8 \pm 0.04 \mathrm{~b}$ & $4.2 \pm 0.3 \mathrm{~b}$ & $331 \pm 38 \mathrm{~b}$ & $0.70 \pm 0.06 \mathrm{~b}$ & $0.32 \pm 0.04 \mathrm{~b}$ & $149 \pm 20 \mathrm{a}$ & $19.7 \pm 8.2 \mathrm{a}$ \\
C & $7.3 \pm 0.06 \mathrm{a}$ & $3.7 \pm 0.4 \mathrm{a}$ & $82 \pm 28 \mathrm{a}$ & $0.60 \pm 0.06 \mathrm{ab}$ & $0.30 \pm 0.05 \mathrm{~b}$ & $234 \pm 25 \mathrm{~b}$ & $19.4 \pm 6.0 \mathrm{a}$ \\
\hline
\end{tabular}

Small letters $\mathrm{a}, \mathrm{b}$, and $\mathrm{c}$ indicate the significant difference among soil $\mathrm{A}, \mathrm{B}$ and $\mathrm{C}$ at $\mathrm{P}<0.05$ level.

Table 3. Summary of ANOVA test for effects of incubation time (D), slurry (S) and urea $(\mathrm{U})$ and multi-ANOVA for all possible interactions on all selected soil properties for each soil.

\begin{tabular}{|c|c|c|c|c|c|c|c|c|}
\hline & & $\mathrm{pH}$ & $\mathrm{TC}$ & CWOC & $\begin{array}{c}\text { CWOC:T } \\
\text { C }\end{array}$ & SR & $\beta$-glucosidase & CM-cellulase \\
\hline \multicolumn{9}{|c|}{ Main effect } \\
\hline \multicolumn{2}{|c|}{ Soil } & $* * *$ & $* * *$ & $* * *$ & $* * *$ & $* * *$ & ** & * \\
\hline \multicolumn{2}{|c|}{ Days } & ns & $* * *$ & $* * *$ & $* * *$ & $* * *$ & $* * *$ & $* * *$ \\
\hline \multicolumn{2}{|c|}{ Slurry } & $\mathrm{ns}$ & ns & ns & ns & * & ns & ns \\
\hline \multicolumn{2}{|c|}{ Urea } & $* *$ & ns & $* *$ & $* * *$ & * & ns & ns \\
\hline \multicolumn{9}{|c|}{ Interactions } \\
\hline \multirow[t]{5}{*}{ Soil A } & $\mathrm{D}$ & $* * *$ & $* * *$ & $* * *$ & $* * *$ & $* * *$ & $* * *$ & $* * *$ \\
\hline & S & ns & ns & ns & ns & ns & ns & ns \\
\hline & $\mathrm{U}$ & $* *$ & ns & * & $* *$ & ns & ns & ns \\
\hline & $\mathrm{D} \times \mathrm{S}$ & $\mathrm{ns}$ & * & ns & ns & ns & ns & ns \\
\hline & $\mathrm{D} \times \mathrm{U}$ & * & ns & ns & ns & * & ns & * \\
\hline \multirow[t]{5}{*}{ Soil B } & $\mathrm{D}$ & $* * *$ & $* * *$ & $* * *$ & $* * *$ & $* * *$ & $* * *$ & $* * *$ \\
\hline & S & $\mathrm{ns}$ & $\mathrm{ns}$ & ns & ns & $* *$ & ns & ns \\
\hline & $\mathrm{U}$ & $* * *$ & ns & $* *$ & $* *$ & ns & ns & ns \\
\hline & $\mathrm{D} \times \mathrm{S}$ & ns & * & ns & ns & ns & ns & ns \\
\hline & $\mathrm{D} \times \mathrm{U}$ & $* *$ & ns & ns & ns & * & ns & ns \\
\hline \multirow[t]{5}{*}{ Soil C } & $\mathrm{D}$ & $* * *$ & $* * *$ & $* * *$ & $* * *$ & $* * *$ & $* * *$ & $* * *$ \\
\hline & $S$ & $* * *$ & $* *$ & $* *$ & $\mathrm{~ns}$ & $\mathrm{~ns}$ & $\mathrm{~ns}$ & ns \\
\hline & $\mathrm{U}$ & $* * *$ & $\mathrm{~ns}$ & $* * *$ & $* *$ & $* * *$ & ns & ns \\
\hline & $\mathrm{D} \times \mathrm{S}$ & $* * *$ & $\mathrm{~ns}$ & ns & $\mathrm{ns}$ & $\mathrm{ns}$ & $\mathrm{ns}$ & $* *$ \\
\hline & $\mathrm{D} \times \mathrm{U}$ & * & $\mathrm{ns}$ & ns & ns & $* *$ & ns & ns \\
\hline
\end{tabular}

$*, * *, * *$, significant at the $0.05,0.01$ and 0.001 probability levels, respectively; ns, insignificant.

The effect of incubation time (days) for all soil properties was significant for soil A, B and C ( $\mathrm{p}<0.05$; main effect Table 3$)$. For all soils, $\mathrm{pH}$ decreased at day 85 by 0.7 (soil A), 0.2 (soil B) and 0.1 (soil C) compared to the initial pH (Figure 1(a)). Soil TC decreased to 2.35 (soil A), 3.28 (soil B) and 2.83 (soil C) $\mathrm{mg} \mathrm{g}^{-1}$, 
i.e. 30\%, 24\% and 26\%, respectively (Figure $1(\mathrm{~b})$ ). CWOC and the ratio of CWOC to TC showed a similar pattern as they increased to day 4 and then generally decreased to day 28 before the second urea addition on day 31 with peak value on day 32 , a decrease to day 58 before the third urea addition with a peak on day 62 (Figure 1(c), Figure 1(d)). Soil respiration of all three soils showed a decrease from day 1 to day 56, recovery to the original respiration level by day 62 , and another decrease thereafter (Figure $1(\mathrm{e})$ ). For all soils, $\beta$-G had a similar pattern with peak values on day 7 and day 58 (Figure $1(\mathrm{f})$ ). CM-cellulase activity peaked on day 28 and day 58 (Figure $1(\mathrm{~g})$ ). All soil properties changed significantly by incubation days for soil A, B and C ( $\mathrm{p}<0.001$; interaction effect Table 3).

Figure 2 shows the net changes of TC and CWOC for three soils. Net changes of TC were below zero for all soils, showing net loss of soil carbon. For both slurry and urea treatment groups, soil A showed greater net TC changes than soil B and soil C, showing an unexpected greater decomposition of soil carbon in soil A. However, the net changes of CWOC showed different patterns for all three soils, where soil C showed the greatest net loss of CWOC while soil A showed a smaller net change with incubation days.
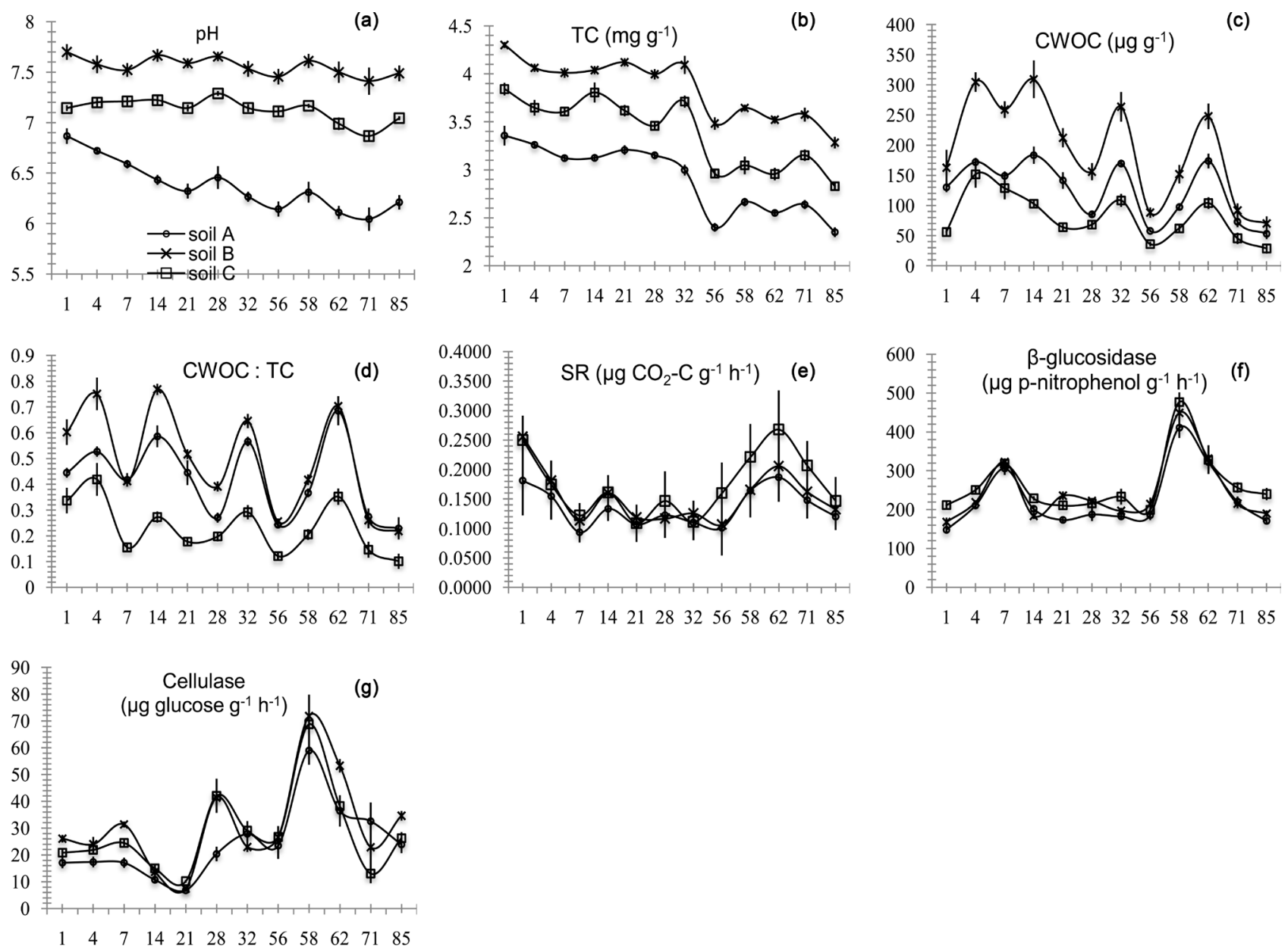

Figure 1. Distributions of selected soil properties for each soil in incubation days. 

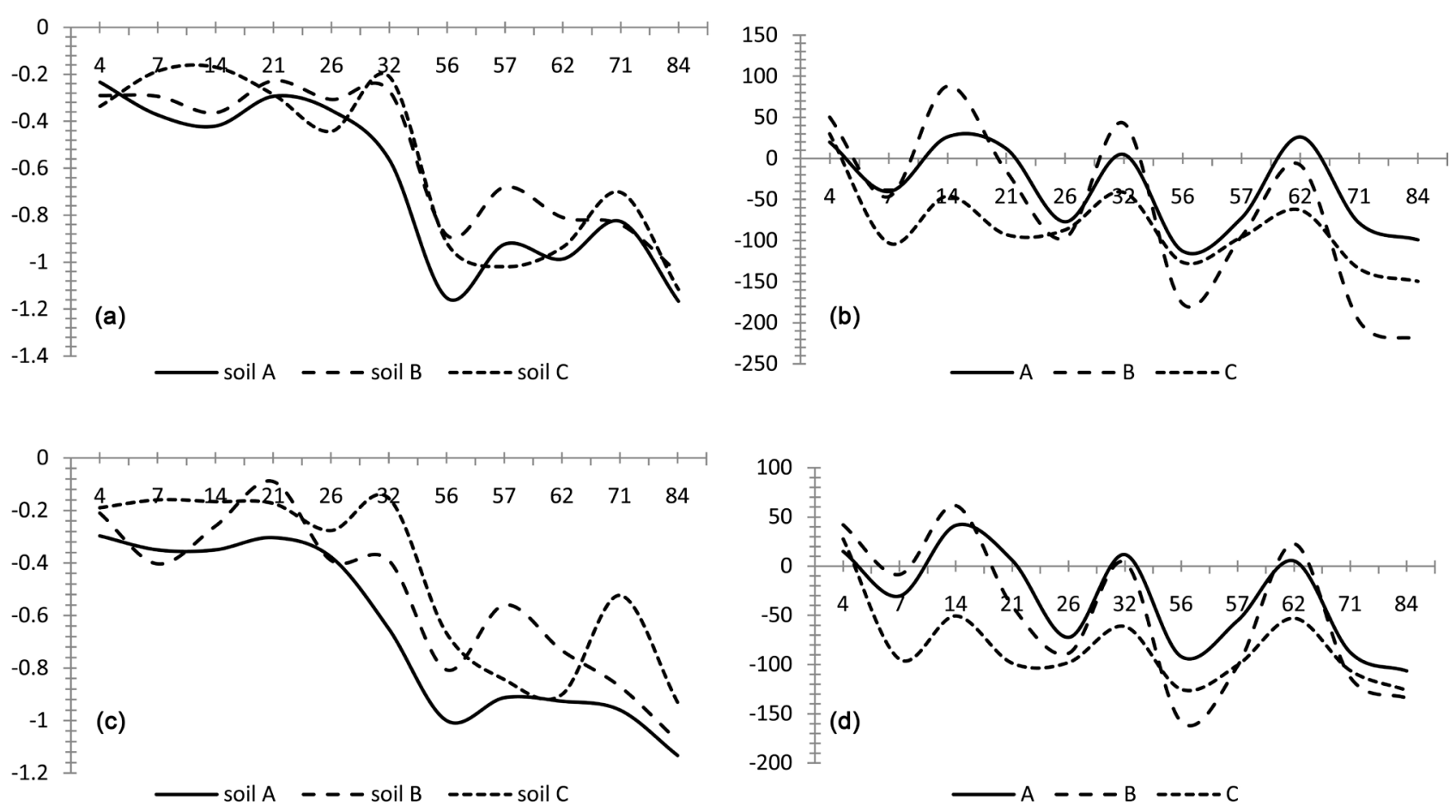

Figure 2. The net changes of TC ((a), $\left.\mathrm{mg} \mathrm{g}^{-1}\right)$ and CWOC ((b), $\left.\mu \mathrm{g} \mathrm{g}^{-1}\right)$ with incubation days in slurry treatment group; the net changes of TC ((c), $\left.\mathrm{mg} \mathrm{g}^{-1}\right)$ and CWOC ((d), $\left.\mu \mathrm{g} \mathrm{g}^{-1}\right)$ with incubation days in urea treatment group.

For soil A slurry did not cause any changes to the selected properties. For soil B, slurry applied to the soil surface caused significantly greater soil respiration than the other treatments. For soil C, slurry addition decreased soil pH significantly and slurry applied on the surface had a greater influence (Figure 3(a)). Slurry increased soil TC and slurry mixed with soil had the greatest TC concentration (Figure $3(\mathrm{~b})$ ). Slurry mixed with soil increased CWOC while slurry applied on the surface decreased CWOC compared to no slurry treatment (Figure $3(c))$. Slurry treatments had no significant influence on CWOC:TC ratio, soil respiration, $\beta-\mathrm{G}$ or $\mathrm{CM}$-cellulase activities (Figures 3(e)-(g)). However, slurry mixed with soil treatment $\left(\mathrm{S}_{2}\right)$ showed a greater net change of TC with incubation days than that in slurry applied on soil surface treatment $\left(\mathrm{S}_{3}\right)$ (Figure 4), meaning a greater $\mathrm{C}$ loss or decomposition during incubation when slurry was mixed with soil.

Urea treatments significantly decreased soil $\mathrm{pH}$ for all soils but there was no significant difference between the $\mathrm{N}_{2}$ and $\mathrm{N}_{3}$ treatments for soils $\mathrm{A}$ and $\mathrm{B}$, but a greater decrease in $\mathrm{pH}$ for the $\mathrm{N}_{3}$ treatment with soil C (Figure 5(a)). TC did not show any change by urea treatment (Figure 5(b)). CWOC and the CWOC:TC ratio decreased significantly with urea addition compared to no urea but no significant difference was found between $\mathrm{N}_{2}$ and $\mathrm{N}_{3}$ treatments for all soils (Figure $5(c)$, Figure $5(d)$ ). Frequent urea application $\left(\mathrm{N}_{3}\right)$ increased soil respiration but urea applied in one dose $\left(\mathrm{N}_{2}\right)$ decreased soil respiration compared to the control of no urea treatment as no change in respiration was observed for soil A or B (Figure 5(e)). $\beta$-G and CM-cellulase showed no significant effect of urea treat- 

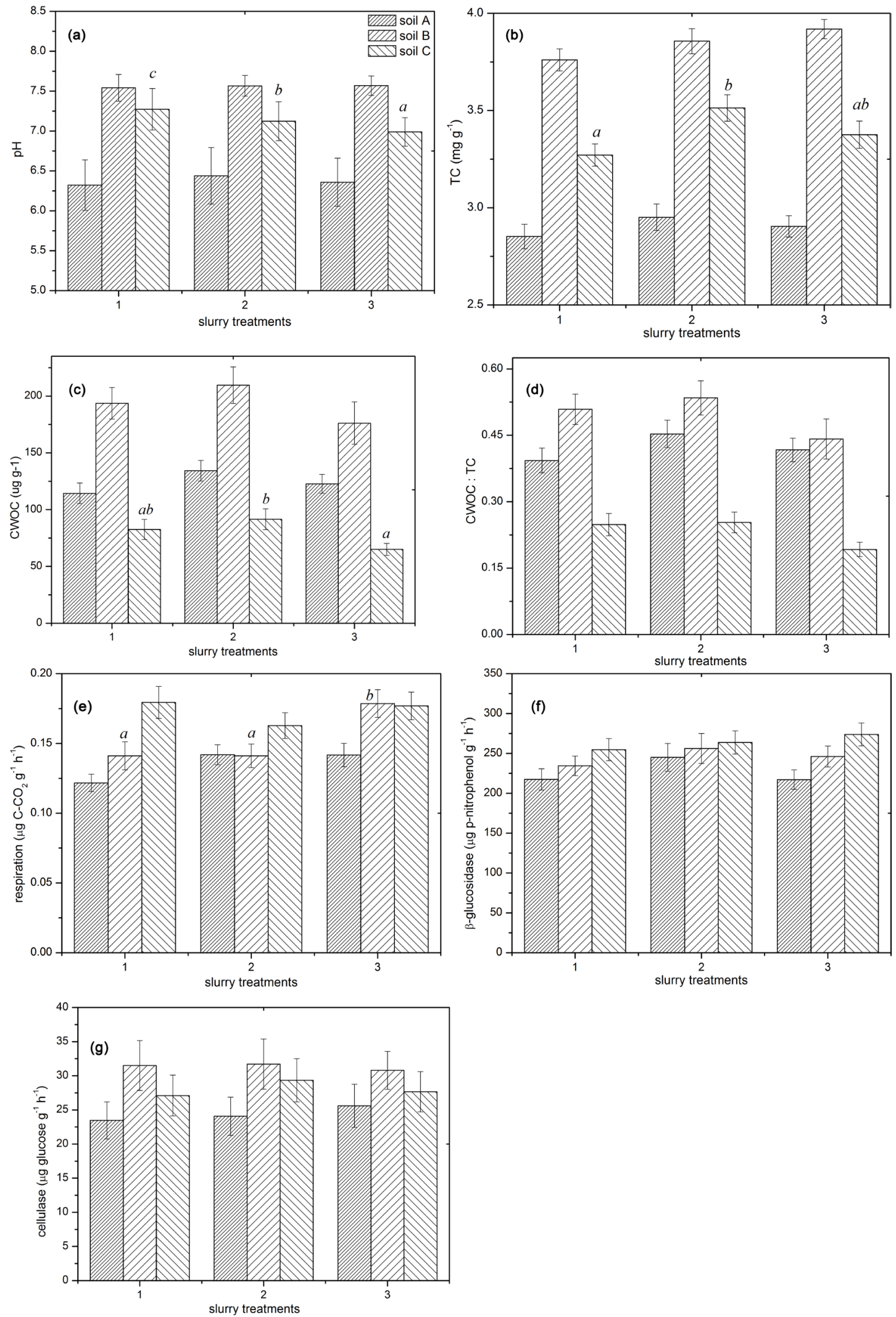

Figure 3. Distribution of soil properties for each soil at different slurry treatments $(1,2$ and 3 in $x$-axis present no slurry, slurry mixed with soil and slurry applied on soil surface treatment, respectively; (a)-(c) letters above error bar in columns for each soil mean significant difference at 0.05 level). 


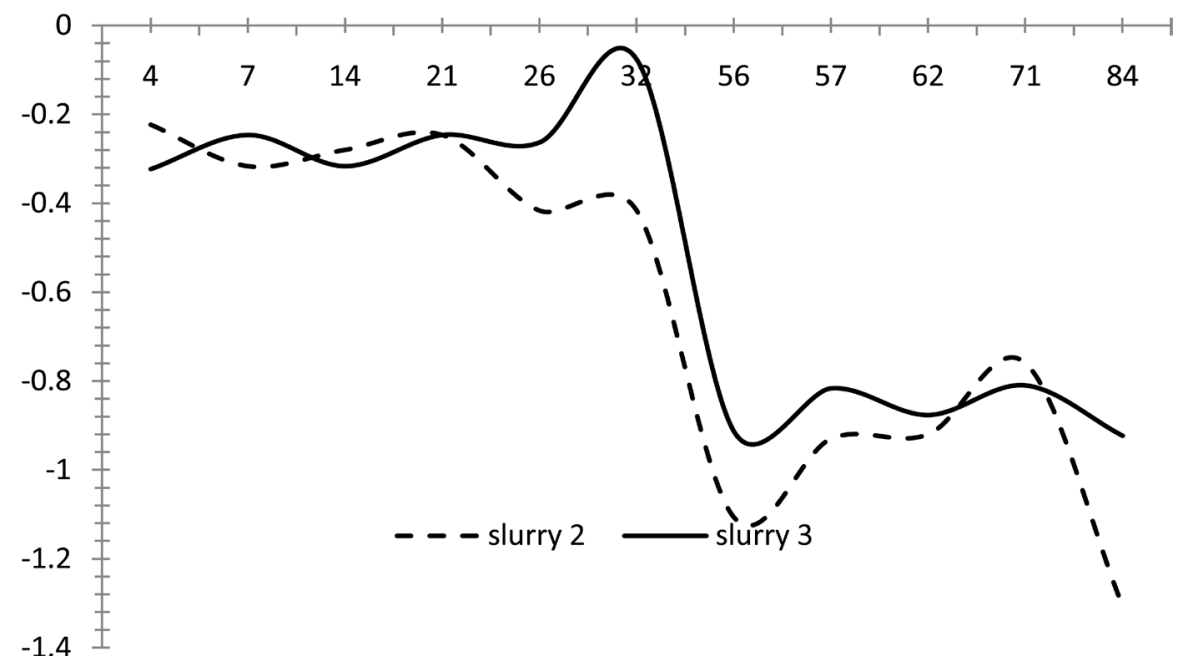

Figure 4. The net changes of TC with incubation days for $\mathrm{S}_{2}$ and $\mathrm{S}_{3}$ treatments.

ment with time (Figure 5(f), Figure 5(g)). The net changes of TC with incubation days (Figure 6) showed one dose of urea application $\left(\mathrm{N}_{2}\right)$ caused a greater soil $\mathrm{C}$ decrease than frequent small dose application $\left(\mathrm{N}_{3}\right)$, indicating a possible greater soil C decomposition by a large dose of urea.

\section{Discussions}

There was no consistent pattern of difference between Soil A and the other two soils, or similarity between Soil B and Soil C before incubation (Table 2), that might indicate recent slurry management had no impact on the properties measured. In some cases Soil A and Soil C were most similar (pH, TC, CWOC) but the data suggested that differences were due to the long-term management history rather than events prior to sampling. The slurry and $\mathrm{N}$ fertilizer applied to soil B and C 3 weeks before soil sampling might have impacts on the results in the incubation. Unfortunately, our data cannot explain the possilibity.

\subsection{Soil Management History}

The evidence of soil A having greater net change in TC with slurry and urea application indicated greater carbon loss, suggesting that the hypothesis of low intensity soil management history delaying response had to be rejected. However, the data cannot explain if the loss of carbon was due to decomposition by enhanced microbial activity during incubation, because soil A showed the lowest soil respiration and enzyme activity before incubation (Table 1 ) and they did not change significantly during incubation. A significant difference for all soil properties was by management history indicating that this was the dominant cause of differences, thus long-term land use intensity and management appears to have been the main cause of the differences observed.

\subsection{Soil Carbon Response to Slurry}

In general, slurry addition increased microbial activity in terms of increased soil 

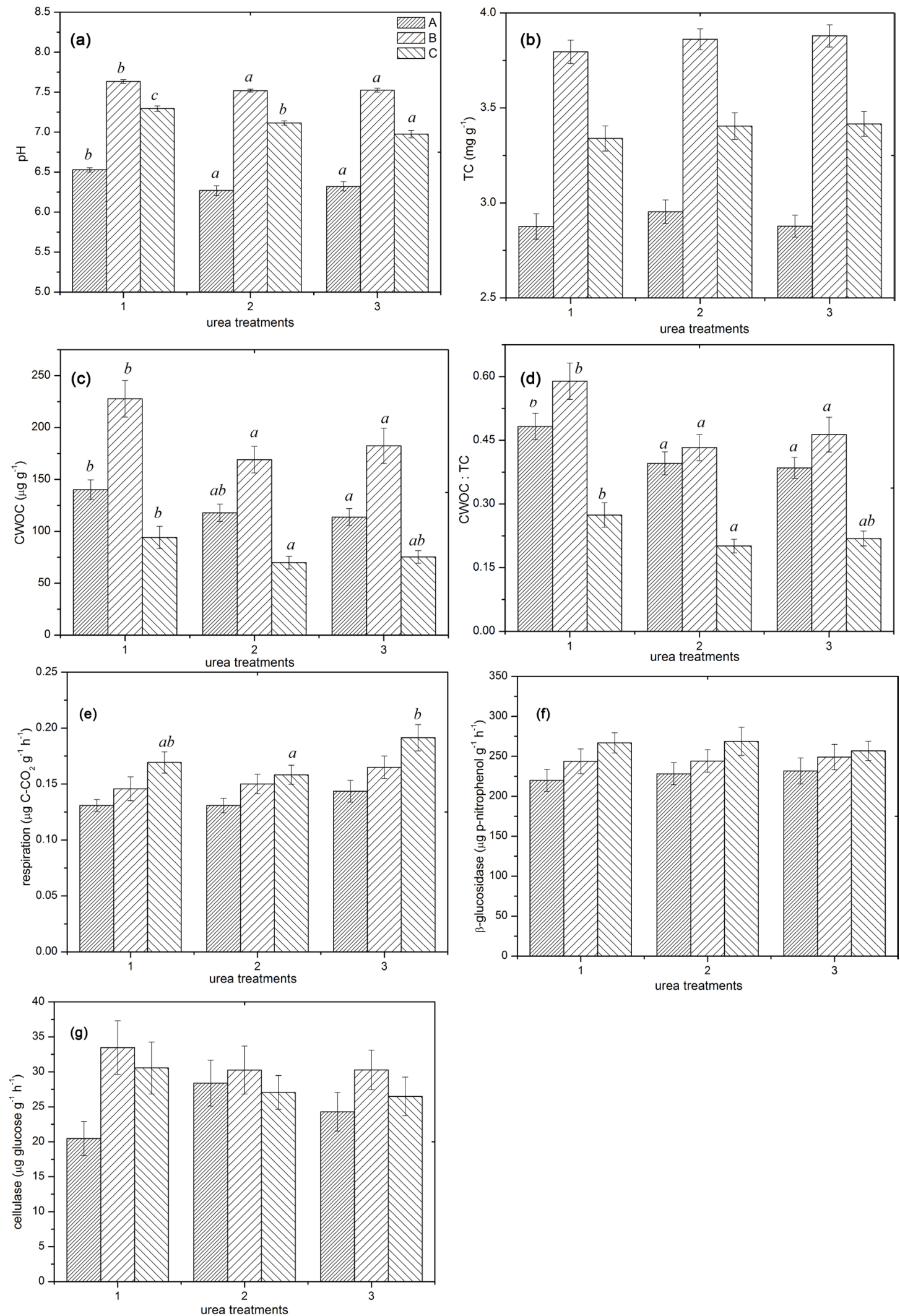

Figure 5. Distribution of soil properties for each soil at different urea treatments $(1,2$ and 3 in $x$-axis present no urea applied treatment, urea applied one time before incubation and the same amount of urea applied in three times equally, respectively; (a)-(c) letters above error bar in columns for each soil mean significant difference at 0.05 level). 


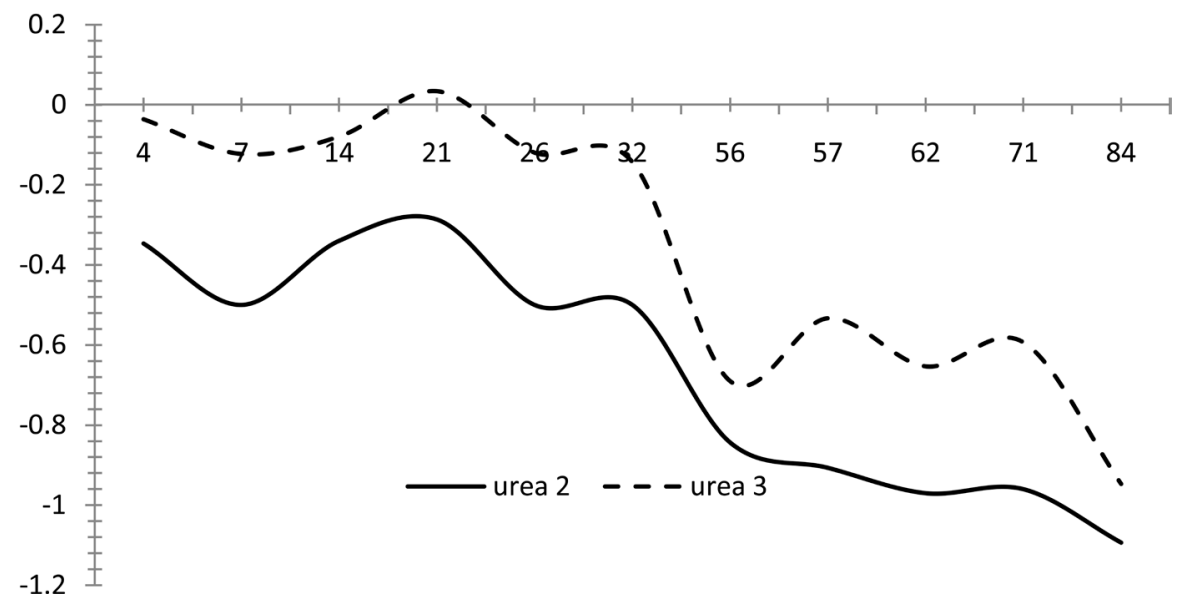

Figure 6. The net changes of TC $\left(\mathrm{mg} \mathrm{g}^{-1}\right)$ with incubation days for $\mathrm{N}_{2}$ and $\mathrm{N}_{3}$ treatments.

respiration (the main effect in Table 3). This can be explained because the application of slurry to land results in enhanced biogeochemical cycling due to the associated inputs of organic matter which stimulate microbial activity. There was little evidence of greater microbial activity under the mixing scenario (just slightly greater cellulose activity, Figure $3(\mathrm{~g})$ ), however, the greater TC net change in slurry mixed with soil treatment confirmed the hypothesis that the mix treatment, mimicking shallow injection would result in a greater TC loss compared to slurry applied on the soil surface. This proportion of TC loss might be as methane $\left(\mathrm{CH}_{4}\right)$ emission owing to limited oxygen availability when slurry is direct injected into the soil, but this incubation experiment could not evaluate these conditions.

During incubation all three soils behaved similarly (Figure 1(b)). Across all treatments there was no difference in rate of response, with a similar pattern for each soil. The change in CWOC during incubation indicated that Soil B was subject to greater oscillations through time (Figure 1(c)), which was then reflected in the CWOC:TC ratio (Figure 1(d)). This pattern could not be explained by soil respiration (Figure $1(\mathrm{e})$ ) or carbon enzyme activity (Figure 1(f), Figure 1(g)).

\subsection{Soil Carbon Response to Urea}

Urea addition resulted in decreased CWOC content that might be attributed to the enhanced soil microbial activity resulting from the availability of nitrate fertilizer. The hypothesis that nitrogen fertilizer applied in one large dose compared to multiple smaller doses would result in less soil carbon decomposition was not supported. The data indicated one large dose of urea caused greater TC loss (Figure 6) than frequent smaller doses. However, this greater TC loss cannot be explained by soil microbial activity in terms of enzyme activity since no differences of enzyme activity were found between the urea treatments (Figure $5(\mathrm{f})$ and Figure $5(\mathrm{~g}))$. It could not be explained by soil respiration because one large dose of urea resulted in a decrease in soil respiration (Figure 5(e)). It ap- 
pears that the TC loss under this condition could not be attributed to biological processes. The significant decrease in $\mathrm{pH}$ and CWOC with urea might be the reason for the enhanced TC loss (Figure 5(a) and Figure 5(c)). Urea addition possibly resulted in decreased soil $\mathrm{pH}$, which ultimately caused a decrease of CWOC by $\mathrm{CO}_{2}$ emission. Unfortunately the data cannot explain why it happened.

There was a greater response to urea application than to slurry applications indicating a greater sensitivity of soil properties to chemical fertilizer over a short time horizon. There was a more rapid and more pronounced response in chemical properties ( $\mathrm{pH}, \mathrm{CWOC}, \mathrm{CWOC}$ TC) than biological properties (respiration and enzyme activities) to urea. Tang, Wang [26] found biological properties to be very sensitive indicators of chemical fertilizer management, but Six, Bossuyt [27] reported that microbial composition and enzyme activity were more influenced by soil properties than management. This study indicates a greater influence of soil long-term management history than short-term urea addition on soil microbial activity and enzyme activity.

Long-term inorganic fertilizer has been shown to cause varied responses in soil microbial function compared to long-term organic fertilization [27]. This study (Figure 5) indicated a decrease of CWOC and the proportion of CWOC in soil TC regardless of management intensity. Compared to urea applied in one large dose, small monthly applications caused a significantly greater microbial response in terms of respiration rate, but only in soil C with high management intensity. This confirms the importance of long-term management history. This study of soil response to urea addition suggests a careful consideration of urea fertilization strategy is required as it had a greater influence on soil chemical properties compared to organic fertilization.

\section{Conclusion}

To conclude, this experiment showed that slurry and urea addition caused greater changes to soil properties for soil with a long-term history of greater grazing intensity than soil under low intensity management. However, slurry and urea application might cause greater soil carbon loss for soil with low management intensity compared to high management intensity. Application of slurry by mixing with soil results in a greater soil carbon loss than slurry applied on soil surface. Urea applied as a single large dose accelerated soil carbon dynamics by increasing respiration rate in the soil and caused greater soil carbon loss compared to multiple smaller dose urea application. Long-term management history seems more important for regulating soil carbon responses to slurry and urea addition, but it is not yet clear how long this influence lasts. With projected increases in grazing intensity and overall management intensity, prediction of soil carbon response should take into account management history.

\section{Acknowledgements}

This project is financially supported by the National Natural Science Foundation 
of China (Grant No. 41501237) and China Scholarship Council \& University College Dublin Joint Scholarship (CSC-UCD scholarship). We thank i) Mohammad Sadegh Askari for assistance in field work, ii) Dr. Thomas Cummins and iii) Ms. Anne Killon for their kindly assistance in laboratory work.

\section{References}

[1] Lalor, S.T.J., et al. (2010) A Survey of Fertilizer Use in Ireland from 2004-2008 for Grassland and Arable Crops. Teagasc: Johnstown Castle Environment Research Centre, Wexford.

[2] Bigorre, F., Tessier, D. and Pedro, G. (2000) Significance of CEC and Surface Area of Soils. How Clay and Organic Matter Contribute to Water Retention Properties. Comptes Rendus De L Academie Des Sciences Serie Ii Fascicule a-Sciences De La Terre Et Des Planetes, 330, 245-250.

[3] Rodrigo Comino, J., et al. (2017) Understanding Soil Erosion Processes in Mediterranean Sloping Vineyards (Montes de Málaga, Spain). Geoderma, 296, 47-59. https://doi.org/10.1016/j.geoderma.2017.02.021

[4] Xu, M., Li, Q. and Wilson, G. (2016) Degradation of Soil Physicochemical Quality by Ephemeral Gully Erosion on Sloping Cropland of the Hilly Loess Plateau, China. Soil and Tillage Research, 155, 9-18. https://doi.org/10.1016/j.still.2015.07.012

[5] Bottinelli, N., et al. (2016) Macropores Generated during Shrinkage in Two Paddy Soils Using X-Ray Micro-Computed Tomography. Geoderma, 265, 78-86. https://doi.org/10.1016/j.geoderma.2015.11.011

[6] Zhong, X.-L., et al. (2017) Physical Protection by Soil Aggregates Stabilizes Soil Organic Carbon under Simulated N Deposition in a Subtropical Forest of China. Geoderma, 285, 323-332. https://doi.org/10.1016/j.geoderma.2016.09.026

[7] Wei, S., et al. (2017) Impact of Soil Water Erosion Processes on Catchment Export of Soil Aggregates and Associated SOC. Geoderma, 294, 63-69. https://doi.org/10.1016/j.geoderma.2017.01.021

[8] Yilmaz, E. and Sönmez, M. (2017) The Role of Organic/Bio-Fertilizer Amendment on Aggregate Stability and Organic Carbon Content in Different Aggregate Scales. Soil and Tillage Research, 168, 118-124. https://doi.org/10.1016/j.still.2017.01.003

[9] Kögel-Knabner, I. (2017) The Macromolecular Organic Composition of Plant and Microbial Residues as Inputs to Soil Organic Matter: Fourteen Years on. Soil Biology and Biochemistry, 105, A3-A8. https://doi.org/10.1016/j.soilbio.2016.08.011

[10] Duarte, R.M.B.O., Fernández-Getino, A.P. and Duarte, A.C. (2013) Humic Acids as Proxies for Assessing Different Mediterranean Forest Soils Signatures Using Solid-State CPMAS 13C NMR Spectroscopy. Chemosphere, 91, 1556-1565. https://doi.org/10.1016/j.chemosphere.2012.12.043

[11] Guerra, A.J.T., et al. (2017) Slope Processes, Mass Movement and Soil Erosion: A Review. Pedosphere, 27, 27-41.

[12] Kravchenko, A.N. and Guber, A.K. (2017) Soil Pores and Their Contributions to Soil Carbon Processes. Geoderma, 287, 31-39.

[13] Jiang, M., et al. (2017) Variation of Soil Aggregation and Intra-Aggregate Carbon by Long-Term Fertilization with Aggregate Formation in a Grey Desert Soil. CATENA, 149, 437-445.

[14] Shi, Y., et al. (2017) Modelling Hydrology and Water Quality Processes in the Pengxi River Basin of the Three Gorges Reservoir using the Soil and Water Assessment Tool. Agricultural Water Management, 182, 24-38. 
[15] Ge, F., et al. (2007) Response of Changes in Soil Nutrients to Soil Erosion on a Purple Soil of Cultivated Sloping Land. Acta Ecologica Sinica, 27, 459-463.

[16] Pezzolla, D., et al. (2013) Short-Term Variations in Labile Organic C and Microbial Biomass Activity and Structure after Organic Amendment of Arable Soils. Soil Science, 178, 474-485. https://doi.org/10.1097/SS.0000000000000012

[17] Alluvione, F., et al. (2013) Short-Term Crop and Soil Response to C-Friendly Strategies in Two Contrasting Environments. European Journal of Agronomy, 45, 114-123.

[18] Collins, J.F. and Brickley, W.D. (1970) Soils of Lyons Estate. Celbridge, Co. Kildare. Soil Bulletin No. 1, Soil Science Department, University College Dublin.

[19] Cui, J., Askari, M.S. and Holden, N.M. (2014) Visual Evaluation of Soil Structure under Grassland Management. Soil Use and Management, 30, 129-138. https://doi.org/10.1111/sum.12100

[20] Alaoui, A., Lipiec, J. and Gerke, H.H. (2011) A Review of the Changes in the Soil Pore System Due to Soil Deformation: A Hydrodynamic Perspective. Soil and Tillage Research, 115-116, 1-15.

[21] Munkholm, L.J., Heck, R.J. and Deen, B. (2012) Soil Pore Characteristics Assessed from X-Ray Micro-CT Derived Images and Correlations to Soil Friability. Geoderma, 181-182, 22-29.

[22] Lalor, S.T.J. (2004) Soils of UCD Research Farm, Lyons Estate. Celbridge, Co. Kildare. Department of Crop Science, Horticulture and Forestry. University College Dublin: University College Dublin, 127.

[23] Anderson, J.P.E. (1982) Soil Respiration. In: Methods of Soil Analysis, Part 2 Chemical and Microbiological Properties, Series Agronomy, Madison, 837-871.

[24] Tabatabai, M.A. (1982) Soil Enzymes. In: Page, A.L., Ed., Methods of Soil Analysis. Part 2-Microbiological and Biochemical Properties, Soil Science Society of America, Madison, 775-833.

[25] Eivazi, F. and Tabatabai, M.A. (1988) Glucosidases and Galactosidases in Soils. Soil Biology and Biochemistry, 20, 601-606.

[26] Tang, C.-S., et al. (2016) Effect of Wetting-Drying Cycles on Profile Mechanical Behavior of Soils with Different Initial Conditions. CATENA, 139, 105-116.

[27] Six, J., et al. (2004) A History of Research on the Link between (micro) Aggregates, Soil Biota, and Soil Organic Matter Dynamics. Soil and Tillage Research, 79, 7-31. 
Submit or recommend next manuscript to OALib Journal and we will provide best service for you:

- Publication frequency: Monthly

- 9 subject areas of science, technology and medicine

- Fair and rigorous peer-review system

- Fast publication process

- Article promotion in various social networking sites (LinkedIn, Facebook, Twitter, etc.)

- Maximum dissemination of your research work

Submit Your Paper Online: Click Here to Submit

Or Contact service@oalib.com 